\title{
Applicable Approach for Controlling Soilborne Root Pathogenic Fungi
}

\author{
Aly MDH, El-Mougy NS and Abdel-Kader MM*
}

Plant Pathology Dept., National Research Centre, 12622, Giza, Egypt

\begin{abstract}
Evaluation of an innovative formula as disinfectant solution for treating seeds or transplants for the purpose of protecting plants during their growth period against soilborne pathogenic fungi was carried out under greenhouse and field conditions. That achieved by adding this formula to plant seeds as seed coating or transplants immerging before sowing. This active mixture include four pharmaceutical commercial active ingredients (Miconazole + Chlorohexidine diglucanate + Chlorocresol + Hexamidine di-isothianate) which are recommended to be used for man health as oral or local treatments against some pathogenic microorganisms. This formula has been successfully applied against the major root rot and wilt plant pathogenic fungi under laboratory conditions. The obtained results were confirmed under greenhouse and field conditions against diseases incidence of tested plants, i.e. Tomato, Bean, Faba bean and Lupin.

This formula considered as applicable active treatment for protecting the agricultural crops against the root pathogenic fungi attacking plants during their growth period starting from sowing up to mature stage, prolonging their healthy life, especially it characterize as safe, cheap, easy applied without harmful residues for man and environment.
\end{abstract}

Keywords: Miconazole; Chlorohexidine diglucanate; Chlorocresol; Hexamidine di-isothianate; Root rot; Soilborne fungi

\section{Introduction}

Soilborne plant pathogens are responsible for many acute and chronic diseases of crop plants that can result in severe losses for growers [1]. Economic losses to soilborne pathogens are estimated at $50-75 \%$ of the attainable yield for many crops. Yield failures resulting from acute diseases such as vascular wilt and root rot may be even more severe and have destroyed entire agriculture industries. About $90 \%$ of the 2000 major diseases of the principle crops in the US are caused by soilborne plant pathogens [2]. It has been estimated that the monetary losses to soilborne diseases is in excess of $\$ 4$ billion / year [3].

For some vegetable and fruit crops, soilborne diseases, weeds, and nematodes have been partially controlled by soil-applied pesticides, including methyl bromide, chloropicrin, and metham. However, the use of soil fumigants for pest control is often undesirable due to unfavorable effects on animals or humans, resulting toxic plant and soil residues, complexity of treatments, and high cost. The solutions to these problems require a large research input. The growing concern over the use of pesticides with respect to human health and environment has brought increasing interest in the use of alternatives characterized by negative impact on the environment. Additionally, resistance of pathogens to fungicides has rendered certain fungicides ineffective, creating a need for new ones with other modes of action.

An alternative to fungicidal application may be the use of pharmaceutical commercial active ingredients. For instance, the combination of Miconazole + Chlorohexidine diglucanate + Chlorocresol + Hexamidine di-isothianate has been recommended for man health against some pathogenic microorganisms.

In this regard, Miconazole is recorded as a potent antifungal activity against common dermatophytes and yeasts with an antibacterial activity against certain Gram-positive bacilli and cocci [4]. Chlorhexidine glucanate, chlorocresol are probably the most widely used biocides in antiseptic products, in particular in handwashing and oral products but also as disinfectants and preservatives. This is due in particular to their broad-spectrum efficacy as antibacterial and antifungal agents [5-7]. Hexamidine is an aromatic diamidine antiseptic which have broad antibacterial and antifungal properties and is also used topically to treat corneal infections and some skin infections [8].

The present work focuses on finding compounds that are safe to human and environment act as fungicides against root pathogens.

\section{Materials and Methods}

\section{Chemical used}

Evaluation the efficacy of the pharmaceutical commercial active ingredients, i.e. Miconazole, Chlorohexidine diglucanate, Chlorocresol and Hexamidine di-isothianate individually or in combination against some major root pathogenic fungi was carried out under in vitro and in vivo conditions. The tested chemicals were purchased from Chemical Industrial Development Company (CID), Egypt.

\section{Source of fungi}

One virulent isolate of each pathogenic fungi Fusarium oxysporum, F. solani; Rhizoctonia solani and Sclerotium rolfsii obtained from Plant Pathology Department, National Research Centre, Egypt were used in the present study. These microorganisms were isolated from the rhizosphere of various root rot wilt infected leguminous and tomato crops, grown in the Delta and Middle Egypt regions, and proved their high pathogenic ability during previous work at the same department [9-14].

*Corresponding author: Mokhtar M. Abdel-Kader, Department of Plant Pathology, National Research Centre, Dokki, 12622, Giza, Egypt; E-mail: mokh_nrc@yahoo. $\underline{\mathrm{com}}$

Accepted December 01, 2010; Published December 02, 2010

Citation: Aly MDH, El-Mougy NS, Abdel-Kader MM (2010) Applicable approach for controlling soilborne root Pathogenic Fungi. J Plant Pathol Microbiol 1:102 doi:10.4172/2157-7471.1000102

Copyright: ( 2010 Aly MDH, et al. This is an open-access article distributed under the terms of the Creative Commons Attribution License, which permits unrestricted use, distribution, and reproduction in any medium, provided the original author and source are credited. 
Fungal cultures were maintained on potato dextrose agar (PDA) slant media at $5 \pm 1^{\circ} \mathrm{C}$ as stock cultures until use. All isolates were refreshed by growing at the optimum growth conditions at the beginning of the present experiments.

\section{Laboratory tests}

The inhibitory effect of different concentrations of Miconazole, Chlorohexidine diglucanate, Chlorocresol and Hexamidine diisothianate individually or in combination on the radial mycelial growth of different root pathogenic fungi was evaluated.

Tested fungal isolates were grown onto PDA medium for 7 days before assay. The tested concentrations, i.e. 100 and its folds up to $800 \mathrm{ppm}$ of each evaluated compound were used. In case of their mixture the same concentrations were prepared in consideration of added an equal share of each compound included to reach the certain concentration needed. The proposed concentrations were prepared in different flasks containing PDA medium, and then poured in Petri dishes, at the rate of $20 \mathrm{ml} /$ dish. Petri dishes containing chemical-free medium were kept as control treatment. Disks, $5 \mathrm{~mm}$ diameter, taken individually from grown fungal cultures were placed in the centre of each Petri dish. Five Petri dishes were used as replicates for each particular treatment as well as control. Inoculated Petri dishes were incubated at $25 \pm 1^{\circ} \mathrm{C}$ for 7 days, then the average diameter of linear growth was calculated.

The influence of Miconazole, Chlorohexidine diglucanate, Chlorocresol and Hexamidine di-isothianate individually or in combination as seed dressing on Tomato; Bean; Faba bean and lupin seeds germination was evaluated under in vitro conditions. The tested plant seeds were coated with each of the previous compound at the rate of $5 \mathrm{ml} / \mathrm{kg}$ seeds. Seed dressing was carried out by applying the tested compounds individually to the gum moistened seeds in polyethylene bags and shacked well to ensure even distribution of the added chemicals. The treated plant seeds were placed between two sterilized layers of wetted filter paper into Petri-dishes. Ten seeds per plate and ten plates as replicates were used. Another set of untreated seeds was used for control. All plates incubated at $20 \pm 1^{\circ} \mathrm{C}$ for 10 days, then the percentage of seed germination was calculated.

\section{Greenhouse experiment}

Effect of Miconazole, Chlorohexidine diglucanate, Chlorocresol and Hexamidine di-isothianate individually or in combination as seed dressing on wilt and root rot diseases incidence of Tomato, Bean, Faba bean and Lupin was studied. Pot experiment was carried out in the greenhouse of Plant Pathology Dept., NRC, during two successive winter growing seasons 2004 and 2005.

The above mentioned pathogens were used in the present experiment. Loamy soil was artificially infested individually (at the rate of $5 \% \mathrm{w}: \mathrm{w})$ with the inoculum of each fungus tested which previously grown for two weeks on sand barley medium (1:1, w:W and $40 \%$ water) at $25 \pm 1^{\circ} \mathrm{C}$. A set of varied infested soils were filled in plastic pots $(20 \mathrm{~cm}$ in diameter) and sown, with relevant to the specific treatment, with tested plants seeds dressed individually with evaluated chemicals at the rate of $5 \mathrm{ml} / \mathrm{kg}$ seeds. Tomato transplants were immersed for $5 \mathrm{~min}$. in stock solutions at concentration of $5 \mathrm{ml} / \mathrm{l}$ of each tested chemical before transplanting.

A set of hypochlorite (2\%) disinfected tested plants seeds or Tomato transplants were sown in artificially infested soils, and served as general check treatment. Five seeds or transplants were sown in each pot and five replicate pots were used for each particular treatment.
Calculation the percentages of root rot disease incidence at preemergence stage was done after 20 days of sowing, followed by the root rot and wilt incidence at post-emergence stage after another 20 days, respectively.

\section{Field experiment}

This experiment was carried out in naturally heavily infested field with wilt and root rot pathogenic fungi located at Al-Aiat territory, Giza governorate, Egypt, during the two successive winter growing seasons 2005 and 2006. The promising and successful applied treatments in pot experiment were evaluated on diseases incidence under field conditions. Miconazole, Chlorohexidine diglucanate, Chlorocresol and Hexamidine di-isothianate individually or in combination as seed dressing or transplants treatment on root rot and wilt of Tomato Bean, Faba bean and lupin disease incidence of were studied.

A field experiment consisted of plots $(7 \times 6 \mathrm{~m})$ each comprised of 12 rows and 60 pits / holes / row which were conducted in randomly complete block design with three replicates (plots) for each particular treatment as well as control. Treated plant seeds of Bean, Faba bean and Lupin or Tomato transplants were sown in all plots, with relevant to the specific host, at the rate of 3 seeds or transplants / pit.

A set of plant seeds or transplants were left as untreated control treatment. The cultivated plots received the traditional agricultural practices. Percentages of root rot incidence at pre-emergence growth stages of Bean, Faba bean and Lupin plants were recorded after 20 , while post-emergence of root rot and wilt incidence of all cultivated plants were 40 days of sowing date.

\section{Statistical analysis}

All experiments were set up in a complete randomised design. One-way ANOVA was used to analyse differences between the chemicals inhibitor effect and linear growth of pathogenic fungi in vitro as well as differences in the activity of seed dressing with different chemical individually or in combination against root rot and wilt incidence of Tomato, Bean, Faba bean and Lupin plants either under greenhouse and field conditions. A general linear model option of the analysis system SAS [15] was used to perform the ANOVA. Duncan's multiple range test at $P<0.05$ level was used for means separation [16].

\section{Results and Discussion}

In the present study, the pharmaceutical chemicals Miconazole, Chlorohexidine diglucanate, Chlorocresol and Hexamidine diisothianate showed highly inhibitor effect against the linear fungal growth of each of Fusarium oxysporum, F. solani, Rhizoctonia solani and Sclerotium rolfsii under in vitro conditions (Table 1). The fungal linear growth reduced as the increasing of chemical concentrations used to reach their completely inhibition between $600-800 \mathrm{ppm}$. It is also observed that the use of a mixture contains the four chemicals in combination cause complete inhibition to the growth of all tested fungi at concentration of $200 \mathrm{ppm}$.

The usage of the tested chemicals showed no inhibitor effect on the germination of Tomato, Bean, Faba bean and lupin seeds. The obtain results revealed that the used chemicals had no toxic effect on seed germination, that the germination percentage of coated seeds was recorded as $100 \%$, while untreated seeds ranged between 82.6$99.2 \%$, therefore these results are not tabulated. 
Citation: Aly MDH, El-Mougy NS, Abdel-Kader MM (2010) Applicable approach for controlling soilborne root Pathogenic Fungi. J Plant Pathol Microbiol 1:102. doi:10.4172/2157-7471.1000102

Page 3 of 5

Under greenhouse conditions, seeds of Tomato, Beab, Faba bean and Lupin were dressing with pharmaceutical chemicals Miconazole, Chlorohexidine diglucanate, Chlorocresol and Hexamidine diisothianate individuallu or in combination. Data in Table 2 showed that reduction in the percentage of root rot incidence in relative to untreated control ranged between $66.6-88.6 \%$ at pre-emergence stage, while it reaches the range $71.1-94.1 \%$ at post-emergence stage.
Similar results were observed concerning the percentage of wilt incidence at both pre and post-emergence stages which recorded at the range of (82.6-91.3\%) and (73.3-88.8\%), respectively.

Results obtained under field conditions were in a harmony with those recorded in pot experiments. In naturally infested field with root pathogenic fungi the percentage of root rot incidence of the same tested plants were decreased relatively to control treatment by

\begin{tabular}{|c|c|c|c|c|c|}
\hline \multirow[b]{2}{*}{ Treatment $^{* *}$} & \multirow[b]{2}{*}{$\begin{array}{l}\text { Concentration } \\
(\mathrm{ppm})\end{array}$} & \multicolumn{4}{|c|}{ Fungi tested } \\
\hline & & Fusarium oxysporum & Fusarium solani & Rhizoctonia solani & Sclerotium rolfesii \\
\hline \multirow{5}{*}{ A } & 100 & $18.9 \mathrm{e}$ & $22.2 \mathrm{c}$ & $26.7 \mathrm{c}$ & $28.9 \mathrm{c}$ \\
\hline & 200 & $25.6 \mathrm{c}$ & $29.9 \mathrm{c}$ & $41.1 \mathrm{~d}$ & $43.3 \mathrm{~d}$ \\
\hline & 400 & $46.7 \mathrm{~d}$ & $45.6 \mathrm{~d}$ & $51.1 \mathrm{bc}$ & $52.2 \mathrm{bc}$ \\
\hline & 600 & $61.1 \mathrm{~b}$ & $63.3 \mathrm{~b}$ & $66.7 \mathrm{~b}$ & $68.9 \mathrm{~b}$ \\
\hline & 800 & $100 \mathrm{a}$ & $100 \mathrm{a}$ & $100 \mathrm{a}$ & $100 \mathrm{a}$ \\
\hline \multirow{5}{*}{ B } & 100 & $21.1 \mathrm{c}$ & $24.4 \mathrm{c}$ & $27.8 \mathrm{c}$ & $31.1 \mathrm{~cd}$ \\
\hline & 200 & $26.7 \mathrm{c}$ & $38.9 \mathrm{~cd}$ & $35.6 \mathrm{~cd}$ & $42.2 \mathrm{~d}$ \\
\hline & 400 & $53.3 \mathrm{bc}$ & $55.6 \mathrm{bc}$ & $56.7 \mathrm{bc}$ & $64.4 \mathrm{~b}$ \\
\hline & 600 & $63.3 \mathrm{~b}$ & $100 \mathrm{a}$ & $100 \mathrm{a}$ & $68.9 \mathrm{~b}$ \\
\hline & 800 & $100 \mathrm{a}$ & $100 \mathrm{a}$ & $100 \mathrm{a}$ & $100 \mathrm{a}$ \\
\hline \multirow{5}{*}{$\mathrm{C}$} & 100 & $10.0 \mathrm{e}$ & $12.2 \mathrm{e}$ & $11.1 \mathrm{e}$ & $8.9 \mathrm{e}$ \\
\hline & 200 & $15.5 \mathrm{e}$ & $17.8 \mathrm{e}$ & $16.7 \mathrm{e}$ & $18.9 \mathrm{e}$ \\
\hline & 400 & $24.4 \mathrm{C}$ & $22.2 \mathrm{c}$ & $23.3 \mathrm{c}$ & $25.6 \mathrm{c}$ \\
\hline & 600 & $41.1 \mathrm{~d}$ & $43.3 \mathrm{~d}$ & $46.7 \mathrm{~d}$ & $54.4 \mathrm{bc}$ \\
\hline & 800 & $100 \mathrm{a}$ & $61.1 \mathrm{~b}$ & $100 a$ & 100 a \\
\hline \multirow{5}{*}{$\mathrm{D}$} & 100 & $13.3 \mathrm{e}$ & $14.4 \mathrm{e}$ & $26.7 \mathrm{c}$ & $15.6 \mathrm{e}$ \\
\hline & 200 & $31.1 \mathrm{~cd}$ & $21.1 \mathrm{c}$ & $44.4 \mathrm{~d}$ & $25.6 \mathrm{c}$ \\
\hline & 400 & $47.8 \mathrm{~d}$ & $30.0 \mathrm{~cd}$ & $47.8 \mathrm{~d}$ & $46.7 \mathrm{~d}$ \\
\hline & 600 & $100 \mathrm{a}$ & $51.1 \mathrm{bc}$ & $100 \mathrm{a}$ & $57.8 \mathrm{bc}$ \\
\hline & 800 & $100 \mathrm{a}$ & $100 \mathrm{a}$ & $100 \mathrm{a}$ & $100 \mathrm{a}$ \\
\hline \multirow{5}{*}{$A+B+C+D$} & 100 & $46.7 \mathrm{~d}$ & $73.8 \mathrm{~b}$ & $40.0 \mathrm{~d}$ & $60.0 \mathrm{~b}$ \\
\hline & 200 & $100 \mathrm{a}$ & $100 \mathrm{a}$ & $100 \mathrm{a}$ & $100 \mathrm{a}$ \\
\hline & 400 & $100 \mathrm{a}$ & $100 \mathrm{a}$ & $100 \mathrm{a}$ & $100 \mathrm{a}$ \\
\hline & 600 & $100 a$ & $100 \mathrm{a}$ & $100 a$ & $100 \mathrm{a}$ \\
\hline & 800 & $100 \mathrm{a}$ & $100 \mathrm{a}$ & $100 \mathrm{a}$ & $100 \mathrm{a}$ \\
\hline
\end{tabular}

Mean values within columns followed by the same letter are not significantly different at $P<0.05(n=4)$.

"The fungal growth reduction in different treatments was calculated as percentage relatively to its growth in control treatment

**Where: $A=$ Miconazole $\quad B=$ Chlorohexidine diglucanate

Table 1: Reduction in fungal growth in response to different concentrations of some pharmaceutical compounds in vitro conditions.

\begin{tabular}{|c|c|c|c|c|c|c|c|c|c|}
\hline \multirow[b]{4}{*}{ Plant } & \multirow{4}{*}{ 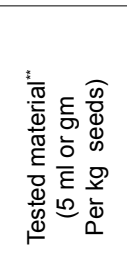 } & \multicolumn{8}{|c|}{ Reduction in disease incidence $\%{ }^{*}$} \\
\hline & & \multirow{2}{*}{\multicolumn{2}{|c|}{$\begin{array}{c}\text { Wilt } \\
\text { F. oxysporum }\end{array}$}} & \multirow{2}{*}{\multicolumn{4}{|c|}{\begin{tabular}{|l|l}
\multicolumn{2}{|c}{ Root rot } \\
Iani & R. solani \\
\end{tabular}}} & & \\
\hline & & & & & & & & \multicolumn{2}{|c|}{ S. rolfesii } \\
\hline & & 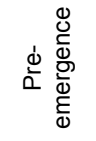 & 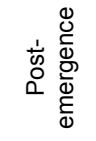 & d & 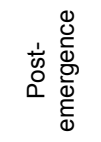 & ఏ் & 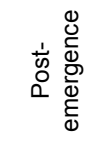 & ఏ. & 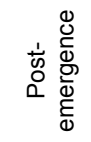 \\
\hline \multirow{5}{*}{$\begin{array}{l}\text { Tomato } \\
\text { transplant }\end{array}$} & A & \multirow{5}{*}{ 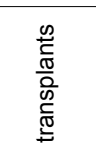 } & $84.6 \mathrm{ab}$ & \multirow{5}{*}{ 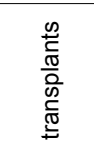 } & $86.8 \mathrm{~b}$ & \multirow{5}{*}{ 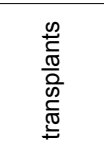 } & $84.4 \mathrm{ab}$ & \multirow{5}{*}{ 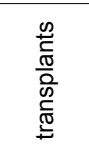 } & $86.6 \mathrm{ab}$ \\
\hline & B & & $87.9 \mathrm{~b}$ & & $88.8 \mathrm{~b}$ & & $89.2 \mathrm{~b}$ & & $88.7 \mathrm{~b}$ \\
\hline & $\mathrm{C}$ & & $92.2 \mathrm{a}$ & & $93.4 \mathrm{a}$ & & 93.6 a & & $91.8 \mathrm{a}$ \\
\hline & $\mathrm{D}$ & & $86.2 \mathrm{ab}$ & & $85.2 \mathrm{ab}$ & & $84.7 \mathrm{ab}$ & & $85.3 \mathrm{~b}$ \\
\hline & $A+B+C+D$ & & 100 a & & 100 a & & $100 a$ & & $100 \mathrm{a}$ \\
\hline \multirow{5}{*}{ Bean } & A & $86.6 \mathrm{ab}$ & $77.4 \mathrm{c}$ & $84.2 \mathrm{ab}$ & $76.1 \mathrm{c}$ & $71.3 \mathrm{~cd}$ & $82.4 \mathrm{ab}$ & $69.7 \mathrm{~d}$ & $94.1 \mathrm{a}$ \\
\hline & B & $84.7 \mathrm{ab}$ & $79.3 \mathrm{c}$ & $86.2 \mathrm{ab}$ & $79.3 \mathrm{c}$ & $76.7 \mathrm{c}$ & $83.6 \mathrm{ab}$ & $71.1 \mathrm{~cd}$ & $88.8 \mathrm{~b}$ \\
\hline & C & $88.8 \mathrm{~b}$ & $87.2 \mathrm{ab}$ & $80.1 \mathrm{ab}$ & $88.2 \mathrm{~b}$ & $80.5 \mathrm{ab}$ & $78.3 \mathrm{c}$ & $72.3 \mathrm{~cd}$ & $83.7 \mathrm{ab}$ \\
\hline & D & $91.3 \mathrm{a}$ & $80.4 \mathrm{ab}$ & $79.8 \mathrm{c}$ & $86.3 \mathrm{ab}$ & $79.2 \mathrm{c}$ & $81.4 \mathrm{ab}$ & $74.1 \mathrm{c}$ & $86.6 \mathrm{ab}$ \\
\hline & $A+B+C+D$ & $100 \mathrm{a}$ & $100 \mathrm{a}$ & $100 \mathrm{a}$ & $100 \quad a$ & $100 \mathrm{a}$ & $100 \mathrm{a}$ & $100 \mathrm{a}$ & $100 \mathrm{a}$ \\
\hline \multirow{5}{*}{ Faba bean } & $\mathrm{A}$ & $82.6 a b$ & $78.7 \mathrm{c}$ & $73.2 \mathrm{c}$ & $75.4 \mathrm{c}$ & $76.9 \mathrm{c}$ & $76.2 \mathrm{c}$ & $66.6 \mathrm{~d}$ & $83.6 \mathrm{ab}$ \\
\hline & B & $87.7 \mathrm{ab}$ & $80.1 a b$ & $74.8 \mathrm{c}$ & $79.6 \mathrm{c}$ & $77.7 \mathrm{c}$ & $79.3 \mathrm{c}$ & $68.7 \mathrm{~d}$ & $87.7 a b$ \\
\hline & C & $85.3 \mathrm{ab}$ & $88.8 \mathrm{~b}$ & $81.6 \mathrm{ab}$ & $86.3 \mathrm{ab}$ & $82.2 \mathrm{ab}$ & $86.8 \mathrm{ab}$ & $71.3 \mathrm{~cd}$ & $94.3 \mathrm{a}$ \\
\hline & D & $90.3 \mathrm{~b}$ & $79.4 \mathrm{c}$ & $88.6 \mathrm{~b}$ & $84.2 \mathrm{ab}$ & $84.3 \mathrm{ab}$ & $82.4 \mathrm{ab}$ & $74.6 \mathrm{c}$ & $87.3 \mathrm{ab}$ \\
\hline & $A+B+C+D$ & $100 \mathrm{a}$ & $100 \mathrm{a}$ & $100 a$ & $100 a$ & $100 \quad a$ & $100 a$ & $100 \mathrm{a}$ & $100 \mathrm{a}$ \\
\hline \multirow{5}{*}{ Lupin } & $\mathrm{A}$ & $83.3 \mathrm{ab}$ & $73.3 \mathrm{c}$ & $82.6 a b$ & $77.7 \mathrm{c}$ & $75.6 \mathrm{c}$ & $72.2 \mathrm{~cd}$ & $67.4 \mathrm{~d}$ & $71.1 \mathrm{~cd}$ \\
\hline & B & $86.5 \mathrm{ab}$ & $71.6 \mathrm{c}$ & $85.9 \mathrm{ab}$ & $76.8 \mathrm{c}$ & $81.2 \mathrm{ab}$ & $76.4 \mathrm{C}$ & $70.3 \mathrm{~cd}$ & $76.8 \mathrm{c}$ \\
\hline & C & $87.4 \mathrm{ab}$ & $74.8 \mathrm{c}$ & $87.3 \mathrm{ab}$ & $79.8 \mathrm{c}$ & $84.4 \mathrm{ab}$ & $79.7 \quad \mathrm{c}$ & $73.4 \mathrm{c}$ & $81.8 \mathrm{ab}$ \\
\hline & $\mathrm{D}$ & 88.8 b & $80.2 \mathrm{ab}$ & $79.8 \mathrm{c}$ & $81.3 \mathrm{ab}$ & $79.8 \mathrm{c}$ & $80.4 a b$ & $79.1 \mathrm{c}$ & $74.6 \mathrm{~cd}$ \\
\hline & $A+B+C+D$ & 100 a & $100 \quad a$ & $100 \mathrm{a}$ & $100 \quad a$ & $100 \quad a$ & $100 \quad a$ & $100 \mathrm{a}$ & $100 \mathrm{a}$ \\
\hline
\end{tabular}

Mean values within columns followed by the same letter are not significantly different at $P<0.05(n=4)$.

* Reduction in disease incidence calculated in relative to that in control treatment

$\begin{array}{cc}\text { "Where: } A=\text { Miconazole } & B=\text { Chlorohexidine diglucanate } \\ C=\text { Chlorocresol } & D=\text { Hexamidine di-isothianate }\end{array}$

Table 2: Reduction in root rot and wilt diseases incidence of some agricultural crops in response to application of some pharmaceutical compounds as seed dressing or transplants treatment under greenhouse conditions. 
Citation: Aly MDH, El-Mougy NS, Abdel-Kader MM (2010) Applicable approach for controlling soilborne root Pathogenic Fungi. J Plant Pathol Microbiol 1:102. doi:10.4172/2157-7471.1000102

Page 4 of 5

\begin{tabular}{|c|c|c|c|c|c|}
\hline \multirow{3}{*}{ Plant } & \multirow{3}{*}{$\begin{array}{l}\text { Tested material } \\
(5 \mathrm{ml} \text { or gm } \\
\text { Per kg seeds) }\end{array}$} & \multicolumn{4}{|c|}{ Reduction in disease incidence $\%^{*}$} \\
\hline & & \multicolumn{2}{|c|}{ Wilt } & \multicolumn{2}{|c|}{ Root rot } \\
\hline & & Pre-emergence & Post-emergence & Pre-emergence & Post-emergence \\
\hline \multirow{5}{*}{$\begin{array}{l}\text { Tomato } \\
\text { transplant }\end{array}$} & A & \multirow{5}{*}{ transplants } & $77.4 \mathrm{c}$ & \multirow{5}{*}{ transplants } & $72.6 \mathrm{c}$ \\
\hline & $\mathrm{B}$ & & $76.7 \quad \mathrm{c}$ & & $76.8 \mathrm{c}$ \\
\hline & $\mathrm{C}$ & & $86.4 \mathrm{~b}$ & & $75.2 \mathrm{c}$ \\
\hline & $\mathrm{D}$ & & $68.4 \mathrm{~d}$ & & $66.2 \mathrm{~d}$ \\
\hline & $A+B+C+D$ & & $100 \quad a$ & & $79.5 \mathrm{c}$ \\
\hline \multirow{5}{*}{ Bean } & $\mathrm{A}$ & $84.3 \mathrm{~b}$ & $71.6 \mathrm{~cd}$ & $66.2 \mathrm{~d}$ & 74.6 \\
\hline & $\mathrm{B}$ & $87.7 \quad b$ & $78.4 \quad \mathrm{c}$ & $68.8 \mathrm{~d}$ & 76.8 \\
\hline & $\mathrm{C}$ & $84.2 \mathrm{~b}$ & $87.2 \mathrm{~b}$ & $70.4 \mathrm{~cd}$ & $68.8 \mathrm{~d}$ \\
\hline & $\mathrm{D}$ & $87.0 \mathrm{~b}$ & $71.3 \mathrm{~cd}$ & $73.1 \mathrm{~cd}$ & $76.4 \quad \mathrm{c}$ \\
\hline & $A+B+C+D$ & $100 \quad a$ & $100 \quad a$ & $100 \mathrm{a}$ & $77.2 \mathrm{c}$ \\
\hline \multirow{5}{*}{ Faba bean } & $\mathrm{A}$ & $77.8 \mathrm{c}$ & 88.4 & $71.1 \mathrm{~cd}$ & $71.1 \mathrm{~cd}$ \\
\hline & $\mathrm{B}$ & $82.3 \mathrm{ab}$ & 79.2 & $82.2 \mathrm{~b}$ & $76.4 \mathrm{c}$ \\
\hline & $\mathrm{C}$ & $77.8 \mathrm{c}$ & 72.4 & $81.7 \mathrm{~b}$ & $82.6 \mathrm{~b}$ \\
\hline & $\mathrm{D}$ & $81.3 \mathrm{ab}$ & $74.8 \mathrm{c}$ & $79.8 \quad \mathrm{c}$ & $81.8 \mathrm{~b}$ \\
\hline & $A+B+C+D$ & $100 \quad a$ & $100 \quad a$ & $100 \quad a$ & $100 \quad a$ \\
\hline \multirow{5}{*}{ Lupin } & $\mathrm{A}$ & $70.4 \mathrm{~d}$ & $80.4 a b$ & $71.4 \mathrm{~cd}$ & $80.3 \mathrm{ab}$ \\
\hline & $\mathrm{B}$ & $84.8 \mathrm{~b}$ & $76.9 \mathrm{C}$ & $76.5 \mathrm{c}$ & 82.8 b \\
\hline & $\mathrm{C}$ & $79.6 \mathrm{c}$ & $79.1 \quad \mathrm{c}$ & $80.4 \mathrm{ab}$ & $74.1 \mathrm{C}$ \\
\hline & D & $81.3 \mathrm{ab}$ & $73.3 \mathrm{~cd}$ & $81.1 \mathrm{ab}$ & 78.6 \\
\hline & $A+B+C+D$ & $100 \quad a$ & $100 \quad a$ & $100 \quad a$ & $100 \quad a$ \\
\hline
\end{tabular}

Mean values within columns followed by the same letter are not significantly different at $P<0.05(n=4)$.

* Reduction in disease incidence calculated in relative to that in control treatment

"Where: $\quad A=$ Miconazole $\quad B=$ Chlorohexidine diglucanate

$$
\begin{array}{ll}
A=\text { Miconazole } & B=\text { Chlorohexidine diglucanate } \\
C=\text { Chlorocresol } & D=\text { Hexamidine di-isothianate }
\end{array}
$$

Table 3: Reduction in root rot and wilt diseases incidence of some agricultural crops in response to application of some pharmaceutical compounds as seed dressing or transplants treatment under field conditions.

the range of (66.2-82.2\%) and (66.2-82.8\%) at pre and post-emergence growth stages, respectively (Table 3 ). Regarding wilt diseases, the incidence reduction were recorded as (77.8-87.7\%) and (71.3-88.4\%) at the same growth stages. It is interesting to note that usage a combination of all tested chemicals as a mixture for seed coating or transplant immersing resulted in $100 \%$ reduction in wilt and root rot incidence of all tested plants at both pre and post-emergence growth stages comparing with each of them individually as well as control treatment.

Antiseptics and disinfectants are used extensively in hospitals and other health care settings for a variety of topical and hardsurface applications. In particular, they are an essential part of infection control practices and aid in the prevention of nosocomial infections [17]. Mounting concerns over the potential for microbial contamination and infection risks in the food and general consumer markets have also led to increased use of antiseptics and disinfectants by the general public. A wide variety of active chemical agents (or "biocides") are found in these products, many of which have been used for hundreds of years for antisepsis, disinfection, and preservation. It is important to note that many of these biocides may be used singly or in combination in a variety of products which vary considerably in activity against microorganisms [18].

These pharmaceutical chemicals successfully proved as antiseptic against human pathogenic bacteria, fungi and yeast. In this regards, Miconazole, an antifungal agent, is used for skin infections such as athlete's foot and jock itch and for vaginal yeast infections. Miconazole combines a potent antifungal activity against common dermatophytes and yeasts with an antibacterial activity against certain Gram-positive bacilli and cocci. Miconazole inhibits the biosynthesis of ergosterol in fungi and changes the composition of other lipid components in the membrane, resulting in fungal cell necrosis $[19,20]$. As for chlorohexidine diglucanate is a good atiseptic with a broad activity spectrum against gram positive and negative bacteria and antifungal action. Its antibacterial and antifungal characteristics are used in propriety medicines for human and veterinary uses [2123]. Moreover, hexamidine di-isethionate and Chlorocresol have also a similar action on human pathogenic microorganisms [24-27].
On the sight of the obtained results in the present invention, it could be conclude that the use of a mixture contains the four pharmaceutical chemicals (Miconazole, Chlorohexidine diglucanate, Chlorocresol and Hexamidine di-isothianate) considered as applicable active treatment for protecting the agricultural crops against pathogenic fungal infection during the growth period starting from sowing up to mature stage, prolonging their healthy life, especially it characterize as safe, cheep, easy applied without harmful residues for man and environment.

\section{References}

1. Chung S, Roberts DP (2002) Biological control for control of soilborne pathogens. Monthly Agriculture and Horticulture p126-127.

2. Lewis JA, Papavizas GC (1991) Biocontrol of plant diseases: the approach for tomorrow. Crop Prot 10: 95-105.

3. Lumsden RD, Lewis JA, Fravel DR (1995) Formulation and delivery of biocontrol agents for use against soilborne plant pathogens. In: Biorational Pest Control Agents, Formulation and Delivery. Hall FR, Barry JW (eds.) American Chemical Soc., Washington, DC. Pp 166-182.

4. Kobayashi D, Kondo K, Uehara N, Otokozawa S, Tsuji N, et al. (2002) Endogenous Reactive Oxygen Species is an Important Mediator of Miconazole Antifungal Effect. Antimicrob Agents Chemother 46: 3113-3117.

5. Russell AD, Day MJ (1993) Antibacterial activity of chlorhexidine. J Hosp Infect 25: 229-238.

6. Rahman MR, Johnson GJ, Husain R, Howlader SA, Minassian DC (1998) Randomised trial of $0.2 \%$ chlorhexidine gluconate and $2.5 \%$ natamycin for fungal keratitis in Bangladesh. Br J Ophthalmol 82: 919-925.

7. Suci PA, Tyler BJ (2002) Action of chlorhexidine digluconate against yeast and filamentous forms in an early-stage Candida albicans biofilm. Antimicrob Agents Chemother 46: 3522-3531.

8. Mullins RJ (2006) Systemic allergy to topical hexamidine. Med J of Aust 185 177.

9. El-Mougy NS (2004) Preliminary Evaluation of Salicylic Acid and Acetylsalicylic Acid Efficacy for Controlling Root Rot Disease of Lupin Under Greenhouse Conditions. Egypt J Phytopathol 32: 11-21.

10. El-Mougy NS, El-Gamal NG, Abdel-Kader MM (2007) Control of wilt and root rot incidence in Phaseolus vulgaris L. by some plant volatile compounds. Journal of Plant Protection Research 47: 255-265.

11. El-Mougy NS, El-Gamal NG, Mohamed MM, Abdel-Kader MM (2008) Furfura approaches as control measures against root rot and root-knot incidence of 
Citation: Aly MDH, El-Mougy NS, Abdel-Kader MM (2010) Applicable approach for controlling soilborne root Pathogenic Fungi. J Plant Pathol Microbiol 1:102. doi:10.4172/2157-7471.1000102

Page 5 of 5

tomato under greenhouse and field conditions. Journal of Plant Protection Research 48: 93-105.

12. El-Mougy NS, Abdel-Kader MM (2008) Long Term Activity of Bio-priming Seed Treatment for Biological control of Faba Bean Root Rot Pathogens. Australas Plant Pathol 37: 464-471.

13. El-Mougy NS, Alhabeb RS (2009) Inhibitory effects of powdered caraway and peppermint extracts on pea root rot under greenhouse conditions. Journal of Plant Protection Research 49: 93-96.

14. El-Mougy NS, Abdel-Kader MM (2009) Seed and soil treatments as integrated control measure against faba bean root rot pathogens. Plant Pathol Bull 18: 75-87.

15. SAS Institute Inc. (1996) SAS/STAT user's guide. Version 6. Vol. 2". 12th edn. (SAS Institute Inc.: Cary, NC) 846 pp.

16. Winer BJ (1971) Statistical principles in experimental design. 2nd edn. (McGraw-Hill Kogakusha Ltd: Tokyo) 596 pp.

17. McDonnell G, Russell AD (1999) Antiseptics and Disinfectants: Activity, Action, and Resistance. Clinical Microbiology Reviews 12: 147-179.

18. Rutala WA (1990) APIC guidelines for selection and use of disinfectants. Am J Infect Control 18: 99-117.

19. Lansdorp D, Bressers HP, Dekens-Konter JA, Meyboom RH (1999) Potentiation of acenocoumarol during vaginal administration of miconazole. $\mathrm{Br} \mathrm{J}$ Clin Pharmacol 47: 225-226.
20. Thirion DJ, Zanetti LA (2000) Potentiation of Warfarin's hypoprothrombinemic effect with miconazole vaginal suppositories. Pharmacotherapy 20: 98-99.

21. Walters TH, Furr JR, Russell AD (1983) Antifungal action of chlorhexidine. Microbios 38: 195-204.

22. Bobichon H, Bouchet P (1987) Action of chlorhexidine on budding Candida albicans: Scanning and transmission electron microscopic study. Mycopathologia 100: 27-35.

23. Ruff ML, McClanahan SB, Babel BS (2006) In vitro antifungal efficacy of four irrigants as a final rinse. Journal of Endodontics 32: 331-333.

24. Denyer SP, Hugo WB, Harding VD (1986) The biochemical basis of synergy between the antibacterial agents chlorocresol and 2-phenylethanol. Int J Pharm 29: 29-36.

25. Brasseur G, Favennec L, Perrine D, Chenu JP, Brasseur P (1994) Successful treatment of Acanthamoeba keratitis by hexamidine. Cornea 13: 379-469.

26. Perrine D, Chenu JP, Georges P, Lancelot JC, Saturnino C, et al. (1995) Amoebicidal efficacies of various diamidines against two strains of Acanthamoeba polyphaga. Antimicrob Agents Chemother 39: 339-342.

27. Seal D, Hay J, Kirkness C, Morrell A, Booth A, et al. (1996) Successful medica therapy of Acanthamoeba keratitis with topical chlorhexidine and propamidine. Eye 10: 413-421. 